\title{
Migrant Labour and Workers' Struggles: The German Meatpacking Industry as Contested Terrain ${ }^{1}$
}

\author{
Peter Birke and Felix Bluhm, University of Göttingen, Germany
}

"Migrants are like ghosts. They come, they work and then they leave" (A Walmart manager, Jaffe, 2014).

\begin{abstract}
This article summarises results of a project whose aim was to analyse the role of migration within the current recomposition of the working class in Germany. We focus on the example of the meat industry in the Oldenburger Münsterland, a region that is experiencing a strong economic boom based on the expansion and modernisation of industrial work. The exploitation of migrant labour, composed of "newcomers" to the industry with both European Union and refugee backgrounds, is a pivotal feature of that boom. Most research on migrant labour focuses on legal frameworks and labour market dynamics. By focusing instead on the labour process, we are able to examine the connections between exploitation, resistance and collective organisation among migrant workers. We show that the experience of migrant workers is not one of complete powerlessness and subjugation. We contrast workers in two sub-sectors, slaughtering and packing on the one hand and industrial cleaning on the other. Although both of these activities are similarly low-wage and migrant-dominated, we find variation in the ability of these workers to exercise power. The importance of skill and the need to avoid turnover gives workers in slaughtering and packing some levers of power, despite their vulnerable immigration status. This power has even instigated a shift towards some formalisation of these jobs on the part of management. In contrast, the different labour process has prevented industrial cleaning workers from accessing the same levels of power, despite sharing a similar labour market position to their co-workers in slaughtering and packing.
\end{abstract}

\section{KEY WORDS}

Migration; refugees; labor unrest; trade unions; subcontracting; meat industry

\section{Introduction}

In 2015, close to a million refugees arrived in Germany. They were welcomed in the country - not only by anti-racist groups, but also by representatives of employers' organisations. This was spearheaded by the CEO of Daimler, Dieter Zetsche, who informed the public about the potential

\footnotetext{
${ }^{1}$ This article is based on a paper presented on 20 July 2018 at the ISA World Congress of Sociology, Toronto. We wish to thank all participants of this session for their useful comments. The article is based on research at the Soziologisches Forschungsinstitut Göttingen (Sociological Research Institute), also conducted by Nicole Mayer-Ahuja, Janos Mertin, Thomas Stieber and Sarah Könecke. Further advice was given by Anda Nicolae Vladu, Basim Saad and Mouna Maaroufi (Potsdam). Our fieldwork, financed by the federal state of Lower Saxony, was only possible through the intense support given by Guido Grüner, ALSO, and Faire Mobilität Oldenburg.
} 
of migration in euphoric terms. Citing claims that 40000 apprenticeship position in Germany remain unfilled, he stated that the newly arrived migrants could create the foundation for a new "economic miracle" (FAZ, 2015). ${ }^{2}$ While the time of miracles is over - due to anti-migrant mobilisations from the far right and repressive state politics against certain groups of migrants the statement indicated a new orientation towards migration, which has been formally established since then. Overall, access to the labour market has been eased, but this is paralleled by the introduction of a workfare regime in migration politics. This also means that humanitarian aspects have increasingly been side-lined (Scherschel, 2016). For example, the government has made it more difficult for EU migrants to apply for certain social benefits in Germany (Riedner, 2017).

From the viewpoint of both business and mainstream labour market research, this increased labour market participation of non-German citizens is widely seen as good news (Brücker et al., 2019). "Labour shortages" can be addressed this way, and part of what makes immigrants attractive to business leaders is the fact that these workers' right to remain in the country depends on their work status. They are perceived as being less likely to organise and exercise collective power. In contrast, the potential vulnerability of these migrant workers is a problem from a labour perspective. In this article, we present a critical assessment of the situation of migrant workers in the low-wage sector in Germany. We focus on the meatpacking industry, where wages are low and almost all workers are immigrants. Our findings show how the migration workfare regime reinforces the vulnerability of migrants working in meatpacking, but also how workers nevertheless (and sometimes against all odds) fight for better conditions at work and the right to stay.

Our article draws on research at three factories in what is probably the most important hub of the European meatpacking industry, the Oldenburger Münsterland, a region situated south of the city of Oldenburg in north-western Germany. ${ }^{3}$ We have interviewed 21 experts and 29 workers or former workers. The experts include managers, works council members and officials from employers' organisations and trade unions. In addition, we have also observed consultation and self-organisation by the workers, and where possible the work process as such.

Accordingly, we go beyond the legal framework and the labour market dynamics which are the subject of most research on migrant labour. By focusing on the labour process, we are able to examine the connections between exploitation, resistance and collective organisation among migrant workers. We show that their experience is not one of complete powerlessness and subjugation. We contrast workers in two sub-sectors, slaughtering and packing on the one hand and industrial cleaning on the other. Although both of these activities are similarly low-wage and migrant-dominated, we find variation in the ability of these workers to exercise power.

From the perspective of management, there is a growing need to avoid turnover and to use the skills of continuously employed workers. This gives workers in slaughtering and packing some levers of power. This power has even instigated a shift towards some formalisation of these jobs on the part of management, with longer-term migrants replacing "posted workers". ${ }^{4}$ In contrast,

\footnotetext{
${ }^{2}$ In the German context, the term "economic miracle" refers to the boom of the West German economy during the 1950s and 1960s.

3 The research presented here is drawn from a larger project, ongoing since 2017, by a team at the Sociological Research Institute Göttingen. We are examining the working conditions of pickers and packers in retail distribution centres, janitors in hospitals and parts of the public sector, in addition to workers in the meat industry. When we finish our larger project in 2020, we will have conducted around 150 interviews with different groups of workers; activists from trade unions, NGOs and workers' centres; state officials; and managers across the three industries.

${ }^{4}$ Under European Union law, citizens of member states are free to work anywhere in the EU. The Posted Workers Directive of 1996 stipulates that employers can send their workers to work on projects of short
} 
the different labour process has prevented cleaning workers from accessing the same levels of power. The meat industry appears to be a laboratory of "differential inclusion"; residential rights and the corresponding labour market positions of migrants differ considerably between groups and shift constantly (Mezzadra and Neilson, 2013).

In contrast to recent migration research, we do not start from the notion that "space" is the new terrain on which antagonistic industrial relations unfold. ${ }^{5}$ In our perspective, mobility is an important terrain of class struggle. A favourable position in the labour market might increase the bargaining power of workers at the point of production, and vice versa. Likewise, labour turnover might be an expression of labour unrest in a Silverian understanding (Silver, 2003), but might also be part of the reorganisation of domination. Our findings contribute to the recent debate on the power resources approach in this journal (Gallas, 2018; Nowak, 2018; Schmalz, Ludwig and Webster, 2018). They caution against conceptualising "power" as something that can be accumulated and invested into class struggle. Instead, we look at the development of power relations based on an analysis of conflicts at the point of production, including politico-strategic consequences for workers' organisations.

Our article proceeds as follows. In the next section, we will sketch the context of the accumulation process and the employment regime in the meat industry by looking at the specific situation in the examined region. After that, we will turn to the analysis of the labour process: We examine the situation of a workforce consisting almost entirely of migrants, comparing and contrasting the labour process of slaughtering and meat processing with industrial cleaning. Whereas our interviewees working in the former field are primarily EU migrants, those working in the latter field are exclusively refugees. While we focus on exploitation and resistance within the factories, we also look at related conflicts around housing, social benefits and resident permits. We conclude by sketching how the contradictions of the employment regime and the labour process influence the scope for collective action and organisation.

\section{The Booming Meatpacking Industry}

\section{Regional development}

The Oldenburger Münsterland consists of the districts of Vechta and Cloppenburg in the state of Lower Saxony. The hub of the German meat industry is somewhat larger than the region and includes the adjacent district of Oldenburg. In addition, in the south it includes the Westfleisch Company in Münster, near the border to the Netherlands, and the Tönnies cooperative in RhedaWiedenbrück, which is by far the largest meatpacking company. Finally, there are some smaller companies in the northern state of Schleswig Holstein (Heinrich Böll Stiftung, 2016: 13). Cloppenburg, one of the poorest districts in Germany until the 1980s, has experienced intense economic growth since the late 1990s. This parallels the case of Vechta. In terms of GDP growth,

duration in other EU countries. Despite the fact that these "posted workers" operate abroad, the labour law of the country of origin still applies - plus a range of minimum labour standards enshrined by the EU. This arrangement has been used by employers to undercut existing collective bargaining agreements and national regulations.

5 There is currently a vibrant debate in research on migrant work on the notion of "space". With reference to Germany, Altenried et al. (2017) propose, based on the work of Sandro Mezzadra, to use the term "logistification" to describe new tendencies of the migration regime. Morrison, Sacchetto and Cretu (2013) have examined migration processes of Moldavian workers to Russia and Italy and see, in the absence of trade unions and collective bargaining, turnover as their most important power resource. 
both districts are constantly placed at the top of the ranking for Lower Saxony, and even for the whole of Germany. Between 2007 and 2016, with the two crisis years as an exception, GDP growth ranged from 4 to 9 per cent, far outstripping the national average ( 0.5 to 3.3 per cent) (Oldenburger Münsterland, 2019).

While the service sector is usually the most important factor of economic growth in Germany, this is not the case in the Oldenburger Münsterland. Both districts show a percentage of employment in the secondary sector far above the national average of around 30 per cent, reaching 44.6 per cent in Cloppenburg (Landkreis Cloppenburg, 2018) and 41.5 per cent in Vechta in 2016 (Landkreis Vechta, 2018). When we look at the places where the meat industry is based, such as the western part of the Cloppenburg district, we find that both industrialised agriculture and manufacturing (including the meat industry) are over-represented. For example, 72.1 per cent of people in the village of Essen (Cloppenburg) - the site of a Danish Crown factory which has around 1400 employees, of which 1000 are employed via subcontractors - work in the secondary sector. In Bösel (Cloppenburg) - seat of the Böseler Goldschmaus factory which has 1268 employees -53.3 per cent of residents work in the secondary sector and 15.2 per cent in the primary sector.

Locations where the meat industry is based are also the most important destinations of migration from within the EU. Of the places associated with central actors in the meat industry, all but one are inhabited by a number of people without German citizenship above or on par with the district's average (Heinrich Böll Stiftung, 2016: 13). However, it must also be mentioned that there has been a recomposition of the migrant workforce in recent years. While workers with Polish citizenship still play a relatively important role, employers have recruited more workers from Romania, Hungary, the Baltic States, and recently Syria and Iraq. Migration is followed by a rise in the total number of inhabitants. While the villages or cities in the area are comparatively small, housing and real estate prices have skyrocketed in recent years. ${ }^{6}$

Scarcity of housing and rents comparable to large cities result in poor housing conditions and contribute strongly to the precarious living situation of migrant workers (Epler, 2014). It is no wonder that the double exploitation of workers by both landlords and factory owners (sometimes united in one person or institute) draws public criticism. In Lower Saxony, there were several scandals that involved migrants living at campsites or in containers (Fiedler and Hielscher, 2017), in rooms with mouldy and damp walls, in accommodation lacking electricity or decent sanitary facilities, and in accommodation associated with fire hazards. ${ }^{7}$ These scandals provided migrant workers with a first opportunity to make themselves heard, often with the help of new initiatives that provide workers with counselling, such as "Fair Mobility", which was launched by the main German union federation DGB. ${ }^{8}$

\footnotetext{
${ }^{6}$ The population figures for 2017 were as follows: Vechta, 30 000; Lohne, 28 000; Cloppenburg, 36 000; Essen, 8 000, Bösel and Garrel, 2000.

${ }^{7}$ One of the main events that finally prompted some attention by politicians in the federal capital Hanover and in Berlin was the death of two Romanian workers in a housing facility near a shipyard in Emden in July 2013.

8 On Faire Mobilität, see their homepage (https://www.faire-mobilitaet.de). In recent times, a similar initiative was launched for workers with refugee backgrounds, called "Faire Integration" (https://www.faireintegration.de).
} 


\section{Economy and employment}

The concentration of capital is increasingly high in the German meat industry. For example, four large companies completely dominate the pork market - and two of them exist mainly because of the relocation of production sites from the Netherlands (VION) and Denmark (Danish Crown), where wages are predominately determined by collective bargaining and workers often earn twice as much per hour as in Germany.

Transnational companies have not only expanded by building new factories, but also by taking over existing ones. For example, Danish Crown's pork-processing factory in Essen was bought from a local competitor in 2010. VION, Tönnies, Danish Crown and Westfleisch jointly produce more than 60 per cent of the total gross value in the sector (Heinrich Böll Stiftung, 2016; Hans Böckler Stiftung, 2017). The biggest player in the industry, Tönnies (12 500 official employees), slaughters and processes no less than 16.2 million pigs a year. In Germany, VION employs around 6000 workers and slaughters and processes around 8.9 million pigs a year (Hans Böckler Stiftung, 2017: 5). The PHW-Wiesenhof group (6 900 official employees) is the major producer of poultry products and slaughters 260000 chickens a day in its Lohne branch alone (Hans Böckler Stiftung, 2017: 5). These numbers signify a steady rise from 1994 to 2014. In this period, pork production has risen by almost 50 per cent, while for poultry it has tripled (Hans Böckler Stiftung, 2016: 8). ${ }^{9}$

However, while output and productivity have risen sharply, the average added value remains relatively small. The meat industry is a booming sector, but only in terms of sales (Hans Böckler Stiftung, 2017: 4). Since 2007, sales figures have risen and productivity has virtually exploded, but profits are made mainly through mass production. In addition, retail companies have tremendous market power and are in many cases able to exert pressure on prices, citing consumer demand.

Because of the relatively small added value, but also because the products are easily perishable, the production process and the logistics associated with it are very vulnerable to disruption. This is even more true insofar as living labour is still - and will continue to be in the near future - a necessary and strategic element of the production process. The technological standard of the work processes we have seen is far from anachronistic, but it is also a long way from full automation. To be sure, there have been experiments with fully automated slaughtering, but they have been unsuccessful to date. Machines simply operate too crudely, thereby ruining the meat. In the words of one manager:

In slaughtering, such machines are introduced only in the recent years. ... In our factory, we have to be very cautious. Yes, I think that robots are in fact vanishing from the companies. Because they work much worse than humans do. If a robot produces 2 per cent rejects, this is a no go. We have maybe 0.1 per cent, and this is already a lot.... Well, I assume we have one of the technically most advanced meat factories. ... But the final step, cutting the pork automatically, ... we don't have that. Here, human beings stand at the conveyor belt. ${ }^{10}$

While the qualifications and experience of meatpacking workers are not negligible, the process (from killing the animals to loading animal parts into trucks) is organised according to the logic of the assembly line. In the three factories we saw, almost every inch of space and every part of the animal is used to produce value. Given the dramatic increase in output, it might seem astonishing that the official statistics state that employment in the meat processing industry has fallen since the

\footnotetext{
${ }^{9}$ In this context, there was rising criticism not only of the conditions of precarious workers, but also and in fact mainly of the standard and quality of the products and of a neglect of animal welfare. This paved the way for cooperation between social movements and trade unions.
}

${ }^{10}$ SOFI-Archive Ref_F_b_E_03_T, translation into English by the authors. 
late 1990s - from 189000 in 1998 to around 160000 in 2018. One reason for this development is the fact that productivity has risen dramatically. However, the main reason for the declining number of employees is the fact that subcontractors have played an increasingly important role; their workers are not included in the industry numbers because they are officially employed by the subcontractors. Depending on which study one consults, subcontracting accounts for between 50 and 90 per cent of the total workforce in slaughtering (Brinkmann and Nachtwey, 2017: 164; Mense-Petermann, 2018).

Only a few years ago, around one-third of the workers were estimated to be posted workers (Wagner, 2015). Three factors are said to have played a part in reducing posted work: the introduction of a minimum wage in Germany (2014-2015); ${ }^{11}$ a so-called "self-commitment" of the six largest meat producers to abolish posted work (2014 and 2015); and a new law at the national level on the responsibility of the main contractors for working conditions of subcontracted employees (2017). The federal employers' organisation of the meat industry claims that under the "self-commitment", 8000 posted workers in companies employing a total of about 32000 workers are now paid "German" wages and social security contributions (VdEW, 2017).

Given the enormous profits arising from the extremely low wages of the posted workers, it comes as no surprise that (officially) non-German subcontractors fiercely resisted the threat of being thrown out of the market due to regulation of the sector, often with the result that the same subcontractors now work under "German" rules. However, while formal employment relations and conditions have changed, this does not mean that workers are able to enforce their rights. For example, while the minimum wage is, on paper, binding for every employer, under conditions created by precarious residence permits and social rights, subcontractors often pay far lower informal wages, including fraud with regard to hours worked and "fees" for materials, tools, transportation and housing (Hirsch and Peter, 2015; Krogmann, 2016). Due to their social and juridical position, workers often refrain from insisting on their formal rights. However, understanding the economic context is not enough for grasping the specific nature of a particular form of employment.

\section{Labour Unrest and the Labour Process in the Meatpacking Industry}

\section{Slaughtering and meat processing}

Our interviews show that the system of exploitation based on subcontracting and informal work has not changed fundamentally since the partial abolishment of posted work. Trade unions and activists from workers' centres that we spoke to have witnessed unpaid overtime and violations of the law on working hours. The fact that subcontractors at the same time act as employer, landlord and supervisor remains a major obstacle in the enforcement of formal rights, be they under German law or not. Wage fraud is still there, even if it has been re-organised. Subcontractors have plenty of opportunities to steal wages, since they are employers, brokers, property owners and providers of transportation. They can make money virtually everywhere in the process.

Workers often do not have any chance to resist, because they are bound to their subcontractors and their right to receive social benefits is restricted. ${ }^{12}$ Sometimes, they do not even own a passport,

11 The sectoral minimum, which was negotiated between employers and unions, was abolished in 2018 (Weinkopf and Hüttenhoff, 2017). This left the sector with an almost total absence of collective bargaining.

12 Under German law, EU citizens who have not worked in Germany previously are not entitled to unemployment and social benefits for five years after they arrive in the country. Thus, since 2014 the main problem faced by migrant workers from the EU is not the residence permit as such, but the work-without- 
as intermediaries seize passports to blackmail people. ${ }^{13}$ Given the absence of trade unions in slaughtering, and the absence of works councils at subcontractors, activists have set up initiatives that support workers. The main aim of Fair Mobility is to provide legal information at workplaces. Other groups, such as Arbeitslosenselbsthilfe (ALSO Oldenburg, Self-organisation of the Unemployed), a local initiative carried by activists, focus on organising the struggle for social rights and benefits (Thommerel, 2014).

In slaughtering, almost all of the workers are migrants, and the vast majority of the workers we met come from EU countries such as Romania, Bulgaria or the Baltic states, which have the formal right of "free movement" within the EU. ${ }^{14}$ Even in the few cases where we found factories that had abolished subcontracting, and thus provided better working conditions, we did not meet a single rank-and-file worker who identified as German. However problematic this identification may be, the workers' perception is that they have Polish, Romanian or other supervisors, while Germans work only in management.

We observed meat processing in three pork factories: The pigs are rendered unconscious by the inhalation of $\mathrm{CO}_{2}$ and killed. They are then hoisted on a rail and exsanguinated, and after that their hair is removed. In an automated process, the exact weight is determined, and the animal is cooled down to facilitate the cutting process. All of these activities involve a maximum of five to seven workers: one or two are needed to force the animals into the machine, one places the animal on the conveyor belt and one is needed to do the actual killing and exsanguinating. Another set of seven to ten workers are then responsible for the removal of the head, the cutting of the body into two parts and the removal of the bowels. Thereafter, cutting, de-boning and the preparation for further processing are performed at the same conveyor belt.

The people we saw worked at a high but relatively continuous speed. Whether the speed of the conveyor belt is increased when retail demand is high during phases like the Christmas season (or when we are not watching) remains unclear. What remains clear is that management's use of workers' time is shaped by the economic contexts described above. There is a strong interest in effectively using not only every inch of factory space, but also every second of working time. A standstill of the conveyor belt during the production cycle needs to be prevented under all circumstances. In two of the three factories we visited, there has been a conversion to continuous production (with individualised and rotating breaks).

However, there are limits to speeding up the pace of work in pork slaughtering, as the partitioning of the animals requires a certain caution. Workers directly involved in slaughtering perform tasks that are often repetitive and physically very exhausting. It appears from our observations and interviews that workers must develop ways of repressing their awareness of what they are doing. Even so, the work environment remains very unpleasant (loud and foul-smelling).

The work is mostly performed by people without formal qualification. At the same time, experience, knowledge of the process, dexterity and skill in handling knives and saws is necessary. Improper cutting can destroy the use value of the animal, for example at the stage when the animal is cut in half with one motion of a large saw. In addition, the process is controlled by at least one veterinarian and by a supervisor who is able to work as a spare man as well. In our interviews with

welfare regime (Carstensen, Riedner and Heimeshoff, 2018).

${ }^{13}$ Cf. SOFI _B_Grüner (interview Grüner, ALSO, 2017-2018). Grüner 2014a.

${ }^{14}$ We conducted three interviews with third-state migrants that came to Germany before 2014. These people had not been allowed to work for many years and were suddenly forced to find work from 2014 onwards due to changing legislation. Today, most of them have been able to leave the meat industry and have found better-paid or less exhausting and dangerous work in other sectors. 
managers, the necessity of supervision, including external supervision, was greatly stressed. This was probably partly due to the increase in public criticism of product quality, and partly to the urgent need to control the workforce due to loss of material and problems related to quickly changing customer demands. In fact, not only are some workers in the line able to damage the product by cutting incorrectly; every worker in the line is potentially able to delay the production process.

\section{The return of Taylorism?}

Under these circumstances, one of the main tendencies we have discerned from management interviews is that they find it increasingly difficult to control subcontractors and thus are trying out different measures to control and stabilise the workforce, or at least to employ some categories of workers for a longer period. Two problems often mentioned in the management interviews are recruiting and language. Subcontracted and informalised recruitment often does not meet company expectations. Moreover, controlling the supervisors provided by the subcontractor might also be difficult, inter alia because of language barriers.

Within the production process, the most important person with regard to controlling and "rationalising" production is the foreman. He has great power to define working conditions, but also the process of production. Thus, it matters whether or not the foreman is provided by a subcontractor. ${ }^{15}$ This can also be seen when turning to the question of communication. Everyday work tasks seem to be communicated by a mixture of German technical terms and a multitude of other languages. It is said that under the regime of subcontracting, factories tend to recruit gangs from one country, but this is not always the case nowadays.

Accordingly, a manager said in an interview:

I have an assembly line that is cutting neck pork. It needs fifteen people. This assembly line now gets a foreman from [the subcontractor]. This foreman is responsible for these fifteen people. What we do not like about the people - man number five, seven, eight cuts wrong. If we cannot talk to the people, then that foreman has to do it. So we need this man from [the subcontractor]. And we need our foreman. Because our specifications are different. Not only is the specification [for cutting]. It's not that this foreman from the [subcontractor], that he understands all that. ... Now [after having introduced direct employment], of course, we have the opportunity ... that our foreman [deals] directly with the people. ${ }^{16}$

As a result of such issues, a company we visited has recently insourced slaughtering, processing and packing. It has agreed to continue employing rank-and-file workers, but, as cited above, has "sacked" the subcontractor's foreman. At the moment, and given the economic success of this firm, insourcing appears to be a relevant option, at least for those companies that have stakes in a more localised and specialised "quality" market where they can command higher prices and face less fierce competition compared to firms producing for the global market.

But in the case of the meatpacking industry, the control problem is not only related to the labour process in a narrow sense, but also to the logistics surrounding it, including qualifications, language training, accommodation and transport. As it turns out, controlling the process presupposes control of recruitment to steady the availability of skilled workers. Furthermore, other functions previously performed by subcontractors are also being taken over, notably

\footnotetext{
${ }^{15}$ It should be added that it has also happened that subcontractors were fined by local courts because the workers were completely integrated into the work process of the main contractor (Nordwest Zeitung, 2017). ${ }^{16}$ SOFI-Archive Ref_F3_E_01_T.
} 
accommodation. Altogether, the efforts in this case to control the wide range of activities bound to the recruitment and reproduction of the labour force is huge. The management in question has already started to build houses for migrants.

Although it might be an option that this specific firm develops from a meat-processing factory into a recruitment and housing agency for migrant workers, it is still open whether the management problem will be solved at all. Moreover, expectations that insourcing will automatically lead to better working conditions should be tempered. A withering away of the subcontractor system is evident at the fringes of the industry, but this will not necessarily entail greater autonomy for workers. The extremely developed division of labour at the conveyor belt in pork slaughtering will hardly be abolished. As for the command of labour power, directly employing workers might be more effective in terms of mastering a vulnerable production process. If we define Taylorism by the managerial ability to structure the labour process in every detail, then this would amount to Taylorisation. But while management strives to control the production process, new forms of labour unrest emerge as well.

\section{Exit strategies of workers}

While the management of some of the firms stress the necessity to change employment relations, the confidence of the workers seems to be increasing. Since 2015, short work stoppages occasionally occurred at Danish Crown and other pork factories, for example against wage fraud (LabourNet, 2015). Awareness is also rising in the social movements, not only about animal rights and ecological problems but also about the working conditions, as visible in the recent demonstrations against Tönnies in Rheda-Wiedenbrück and Kellinghusen. Moreover, it seems that at wildcat strikes in Denmark most of the participants were workers from Eastern Europe, and notably from Poland (Jyllands-Posten, 2017). There is no doubt that the knowledge about such experiences spreads quickly, and that this is not confined to certain groups of workers. For example, three years ago, when Romanian and Bulgarian workers in a meat processing factory in the region walked out to call for permanent employment and the abolition of subcontractors, they announced that either their demands would need to be met or they would "travel home" (NDR, 2016).

To travel home, or rather to quit one job for another one, is one of the most important instruments in accessing higher wages, shorter workdays, and better working and living conditions in general (Morrison et al., 2013). But it is more of an opportunity for some workers than others - especially for those with qualifications considered scarce or complex by the employers. In contrast to tasks such as packing, the partitioning of the animals is - even in a Taylorist setting quite a challenging process demanding experienced workers who cannot be replaced easily. This means that workers can find work elsewhere, and this includes neighbouring countries like Denmark where wages and working conditions are better thanks to stronger unions and the corresponding collective agreements and regulations. As a manager complained, there is, in booming regions like the Oldenburger Münsterland, a good labour market position for some meatpacking workers, resulting not at least from their transnational mobility:

Manager: Getting production helpers or applications, there are a lot, and skilled workers, that is more difficult.

Question: What does 'skilled worker' mean in this context?

Manager: Well, they who really can do everything, they mostly move to Scandinavian countries, or Switzerland. ... In the past, there were quite a few Poles in the slaughter and butchering sector. They are almost completely gone. They almost do not exist anymore in Germany. 
Question: Where to? Where have they gone?

Manager: Denmark. ${ }^{17}$

However, insourcing changes, or at least begins to change, the terrain on which workers struggle - even for those who are still employed by subcontractors. In many cases, our interviewees have described small strikes and other forms of labour unrest, aiming at higher hourly wages and the abolishment of precarious employment conditions. Again, "leaving" seems to be a big issue in those strikes, which most often are neither formally announced nor documented. Importantly, the exit option is not necessarily used quietly and as an individualised survival tactic. An interviewed worker described how the threat of leaving serves workers as a collective practice of resistance:

The Polish guys, forty, fifty people, went to the boss, and they said: Either you give us open-ended contracts or we go. And then, when so many people leave at once, that is of course a problem for them. So, you know, they all together threw their clothes, work clothes, away and down on the floor. Then they left. And then they were intercepted already at the factory gates, come back, come back, and now they all have open-ended contracts. ${ }^{18}$

Due to the informal character of collective arrangements in the meat industry, it might be too early to speak of a generalised improvement of working conditions in slaughtering. But it is clear that at least some capitalists were forced to accept wage hikes in the recent years. The employers' organisation reported that wages in the core processes of slaughtering had to be increased by 10 per cent in 2018 alone - which is far above the average increase of wages in industrial work on a national level. ${ }^{19}$ At the same time, women workers have begun to problematise a gender wage gap, based on the (implicit) assumption that, following insourcing, the "real" employer needs to pay the workers "real" wages. One woman told us that she now gets a slightly higher wage compared to when she was employed by a subcontractor, but this is still much less than many of the male workers who are usually assigned to other positions. She demanded respect for her experience and the quality of her work, which should also be reflected in higher pay. ${ }^{20}$

In sum, new arenas of conflict around wages and working conditions can be observed in slaughtering and meat processing. While it remains open if any of this will lead to an upsurge in collective organisation, it has to be noticed that workers are not defenceless, although their actions are almost never connected to trade union activity in a narrow sense. The question that should follow from this insight is how to connect trade unionism and social movement activism to small strikes and labour unrest at the point of production. We will return to this question below.

\section{Industrial cleaning: refugees at work}

The workers we interviewed in industrial cleaning worked in a large poultry processing factory. They are employed by a subcontractor with around 4200 employees. The company is not only active in industrial cleaning, but also functions as a temporary employment agency, in addition to offering security and building management services. In recent years, the number of employees has skyrocketed because of the growing need for such services and the growing use of outsourcing. In a newspaper interview, the $\mathrm{CEO}$ of the firm explicitly addressed issues that have drawn public

\footnotetext{
${ }^{17}$ SOFI-Archive Ref_F3_E_03, Interview with a manager.

18 SOFI-archive Ref_F1_B_12_T.

${ }^{19}$ In 2018, wages in Germany rose at average between 3 and 4 per cent (www.lohnspiegel.de).

${ }^{20}$ SOFI-Archive Ref_F3_B_01_T.
} 
criticism: "We want our workers to feel well. Paying wages defined by collective bargaining and regular working hours are very important to us" (LN, 2017).

Most of the people we interviewed who work in industrial cleaning are from Syria and have arrived in Germany in recent years, escaping from the war in their home country. We contacted them through a local anti-racist group. Before we describe working conditions in industrial cleaning, one preliminary remark is necessary. In the context of our project, it took us a long time to find the workplaces of refugees. Almost all of the experts we interviewed - be it managers, works council members, officials from employers' organisations or trade unions - were convinced, two years ago, that there were no refugees working in the meat industry. Precarious employment conditions render people invisible. And because migrant workers often work under precarious conditions, they often become invisible (Anderson, 2006; Dyer, McDowell and Batnitzky, 2010). Today - as was the case two years ago - people living in camps and with uncertain residence status do in fact work in many parts of the meat processing industry. However, many of them work in those jobs that offer the least contact with fellow workers.

At the same time, invisibility is organised on the shop floor through managerial decisions. For example, workers from the subcontractor in the above-mentioned poultry factory told us that they were not allowed to use the break rooms of the workers employed directly by the company. There is also a literal aspect to invisibility. In general, many people who have arrived from "secure third states", and whose residence status is tenuous, work night shifts in Germany. ${ }^{21}$ While the minimum workload at this subcontractor is five nights per week, some workers we interviewed had not taken a single day off in months. Total hours worked were more reminiscent of early industrialisation than of modern, regulated, legal conditions. Apart from the fact that this destroys the health of the worker, such working hours are illegal under German law. In migration research, such features have often been discussed as a result of illegalisation, but this is notably not the case here. Quite the opposite: it is formal, regular work.

Industrial cleaning in the meat industry is one of the tasks for which subcontractors not only hire refugees but also migrants from within the EU, particularly from Eastern Europe. As in the case of slaughtering, the supervisor is usually a migrant, as is, in most cases, the object manager (that is, the person responsible for all workers employed by the subcontractor). Insofar as there are any people perceived as Germans, they are typically those whom the main contractor sends to control the performance of the cleaners in the early morning, before production resumes. Or, they might be employees of the premises, who tell the subcontracted workers that they are not allowed to use a certain facility or room. This means that people who share the experience of migration supervise most of the everyday work. Our interviewees claim unanimously that "old" migrants (migrants who arrived earlier in the country) organise the labour process, and most of them hint at the fact that some of those "old ones" give better jobs to people from their own community.

This is not by chance, because the recomposition of the workforce also involves the redefinition of hierarchies based on "racification" (Dyer et al., 2010: 118; Samers, 2014). Most of the managers in our interviews constantly hinted at "bad" or "good" characteristics of groups of workers, and they "naturally" defined these groups by their nationality or race. Moreover, certain

\footnotetext{
${ }^{21}$ It is difficult for unskilled workers or workers whose skills are not recognised to immigrate to Germany legally. As a result, many of them seek political asylum in order to be allowed into the country. Under European rules, however, people who have transited through so-called "secure third states" have no claim to do so, even if they have faced repression and persecution in their home countries. It is presumed that they could have sought asylum in those "third states". This regulation completely ignores that many asylum seekers have personal and family ties in Germany, and that asylum seekers in transit countries often have to put up with dire living conditions.
} 
nationalities might be characterised as "diligent and hard-working" by one manager, and as "lazy and rebellious" by the next. Such assumptions qualify not only as racism (Bojadžijev, 2012: 25), but are structurally intertwined with a continuous stratification of migrant workers, which again is the main form of exploitation in industries like meat processing. Differential inclusion, with the regulation of individual movement by the state, is thus both a reflection of racism and a decisive feature in the valorisation of migrant labour. ${ }^{22}$

Although refugees from Syria normally would have residence permits of three years and are not under the threat of immediate deportation, secure residential status is linked to certain criteria. People recognised as refugees also have to learn German and pay their own expenses. This means they must either be in a training programme or already "integrated" in wage work. So there is a rationale for being employed in industrial cleaning, not in spite of but because it is documented and official work. From the perspective of management, refugee workers can be attractive in sectors with a high turnover - for example, in the cleaning and meat industries - as the state partly covers the workers' reproduction costs, restricts mobility and in some cases even takes care of recruitment. In our interviews, people mentioned additional pressure related to the government's efforts to restrict the regulations on family reunions as part of the asylum procedure during the rollback against asylum seekers after 2015. Many of the workers interviewed formally arrived as "guests" of friends or relatives, meaning that those friends or relatives signed a "letter of guarantee" - that is, a declaration by which a person assumes full responsibility for the costs incurred by a foreigner. Some of them still had families - wives or husbands, children, parents - stuck in the Syrian war and needed to accept any kind of paid work in order to keep their residence permits and maintain the hope of a future reunion with their loved ones.

Furthermore, in Germany, as in other countries, there is currently a strong public discourse about "undeserving" migrants. Against this backdrop, the wish "to earn my own income" is understandable, and a certain positive view on the part of the interviewees of the principles of workfare results from that wish. In addition, all people interviewed were men; all of them sent money to Syria, most had children in Germany as well as in Syria and some of them identified with the male breadwinner model. Their worst-case scenario was to be dependent on someone else's income, be it a person from their own family or not.

Under the 2016 Integration Act, the permission for refugees to stay in the country is linked to their preparedness to take up waged work (or gain qualifications in order to so), even if it is under the worst conditions imaginable. In addition, wages in industrial cleaning are, at least officially, slightly above the minimum wage. Our interviewees receive a monthly net income of 1700 to 2200 Euros a month - an amount which they only earn because of the extreme working hours already mentioned.

The comparatively high income does not mean that the workers are satisfied with their conditions. Their anger is prompted, in particular, by working conditions familiar from other jobs in the meat industry, in particular work hours "stolen" by management As in meat processing, exploitation starts even before the worker has begun working. Often, the person arranging for workers to find a job requires them to pay a "fee". Obviously, bribing one's foreman or colleague to "bring someone in" is informal and illegal, but also a well-established practice. We heard of jobseekers paying 750 Euros for "hard work" and 1500 Euros for "better work". Once they had been "brought in" successfully, our interviewees' working night began at 8 p.m. They arrived, put on their working clothes and fetched the necessary materials (tools and cleaning chemicals). In contrast

\footnotetext{
22 Under German law, there are restrictions as to where in the country an individual asylum seeker or refugee is allowed to live.
} 
to the claims made by the CEO mentioned above, official work hours begin at 9 p.m., so their first work hour was not paid, which is illegal. In addition, interviewees reported that they were not paid in case of illness.

\section{Dry and wet cleaning}

On the shop floor, cleaning comprises two different tasks, generally speaking. Those who clean the sector of the factory near the delivery entrance work in groups of three led by a foreman. Their task is "dry" cleaning, which means there is little use of chemicals. In this area, the share of women is higher than in those groups responsible for the "wet" cleaning of machines. Interviewees employed in dry cleaning consider themselves comparatively lucky, because supervision is weak and it is easy to acquire knowledge about how to make everything look acceptable. ${ }^{23}$ On the other hand, workers have to clean large spaces and are bound by an often highly compressed time schedule (Mayer-Ahuja, 2003). In dry cleaning, a group of three has to cover 6000 square meters a night.

Cleaning the machines or "wet cleaning" is a task notorious for its poor health and safety conditions. Interestingly, this is not in spite of but because the main contractor needs to monitor the cleaning of the machines much more closely than virtually everything else in the production process due to scandals over food quality. This is especially true in poultry slaughtering, where ecological and animal rights concerns have dominated the public discourse for quite some time. In other words, "perfect" cleaning is required here - at least officially. At the same time, the interviewees complained that the subcontractor did not train them well enough to perform the task, so that much is learned "by doing", which means that risks associated with cleaning the machines are not properly explained to workers. In combination with an accelerated work pace, this leads to severe problems. For example, workers put their health at risk by not using safety masks, and they work with hazardous chemicals and dangerous machines. Our interviewees reported two serious workplace injuries during the weeks when we conducted our research; indeed, a worker lost an arm because he was not introduced adequately to the "wet" cleaning of machines. ${ }^{24}$

Due to the nature of the production process, the time schedule of all workers employed in industrial cleaning can be chaotic. Often, when slaughtering and processing is not finished by 9 p.m., workers are forced to work through their half-hour break, without being paid for this time. In addition, the inspection and approval of the cleaning takes place early in the morning, around 4 a.m., which means that the workers have to be very fast to complete their tasks, especially when they are not able to start the cleaning process due to delays in meat processing. After their work has been checked and they have done additional cleaning, the shift ends between 6 and 7 a.m.

Asked about their personal wishes, all cleaners explained that planning a career in this job makes no sense. Depending on their social background, and just like the majority of workers in slaughtering, they search for a way out. They try to find another job where they can use skills acquired in previous jobs, or they plan to study. In the meantime, there are hints of resistance, even within the group of absolute newcomers. In the case we examined, some of the workers became angry because of what they perceived as unequal pay for identical activities. They discussed approaching the works council, but refrained from doing so at the last moment. Many of them later attended a collective counselling meeting organised by local anti-racist groups with the help of a trade union official. The main steps they agreed at this meeting were to write down work hours

\footnotetext{
${ }^{23}$ SOFI-Archive, F2_B_03_T.

${ }^{24}$ SOFI-Archive Ref_F2_B_04_T.
} 
individually and collectively to prevent employers from stealing "time", and to act against the practice of "bribing". They only carried out these steps to a degree because most of the interviewees and participants in the meeting left their workplace very soon thereafter.

However, such emerging conflicts around wages and working conditions are ongoing and the outcome remains unclear. It appears that management is growing alarmed, given the possible negative publicity. One indication of this is that we heard of central management visiting the poultry factory to inspect the work process. Nevertheless, it is much more difficult for the cleaners to develop bargaining power than for their colleagues involved in slaughtering process, because in cleaning it is much easier for the companies to cope with labour turnover. To be sure, industrial cleaning is a process that requires experience to be carried out quickly and safely. (An experienced cleaner told us that a learning period of several months is required.) However, in this situation a lack of experience becomes mainly a problem for the workers, not for the companies. Consequences are a rising risk of accidents and a longer time needed to complete the tasks, but inexperience does not directly lead to a reduced product quality or the loss of material as is the case with slaughtering. The lesser efficiency of inexperienced cleaners is compensated by the (illegal) expansion of working hours and the cancellation of breaks as well as by work intensification.

\section{Conclusion}

This article has examined the labour process of migrant workers in the meatpacking industry. We have shown that these workers are not as defenceless, as the common narrative suggests. The importance of knowledge and control within the labour process remains, even for workers whose legal status creates structural vulnerability. In the case of slaughtering and meat processing, some migrant workers have learned how to acquire and withdraw knowledge in the labour process. In the context of a favourable labour market position which allows frequent exit and turnover, they have been able to use their knowledge about the vulnerability of the production process in their own interest. This leads to two findings. First, the exit option of the workers is deeply connected to their power at the point of production; second, labour turnover is - apart from bad publicity surely the main reason for the far-reaching abolishment of posted work and the tendency of insourcing within the sector. The shift to permanent employment in some of the meat companies, then, lays the groundwork for struggles around wages and conditions inside the factory.

But a turn to permanent employment in the meat sector does not mean that the conditions of work will necessarily improve. The work process will remain intensely paced, monotonous and physically demanding. The insourcing of some workers and the shift from temporary to longerterm migrants is not aimed at improving conditions. Rather, it is part of an ongoing struggle between employers and workers for control over the production process as whole. This also explains management's involvement in recruiting activities and in the provision of accommodation. In this sense, control at the point of production parallels the ambivalent development of the border regime: the opening of the labour market is followed by drives to define new rules and standards for recruitment and exploitation. And the sample from industrial cleaning shows how "boundary drawing" (Silver, 2003) systematically limits the scope for workers' resistance, as there is also a segmentation between "old" migrants from the EU and "new" migrants from Syria and other warridden states.

"Leaving" is, in this sense, a privilege of some workers, and their strategies might diffuse to others and produce new arenas of labour unrest, but this is not automatically the case. Notably, the exit option is effective because trade unions and collective agreements exist elsewhere (for 
example, in Denmark), but not in most of the factories in Germany. It remains an open question if and how the favourable situation of some workers in the labour market can be translated into self-organisation and the establishment of trade unions. Furthermore, can their comparably better position stabilise existing hierarchies in the workplace, for example along gender lines? While trade unions are still weak and often totally absent, our material shows that forms of labour unrest are indeed visible.

The absence of trade unions means - in both cases under examination - that their presence is more indirect, and mainly mediated by consulting initiatives such as Fair Mobility and Fair Integration. Those initiatives (plus local churches, individual trade unionists and lawyers) publicly and repeatedly criticise living and working conditions of migrants - in the Oldenburger Münsterland, but also at the Tönnies factory in Rheda-Wiedenbrück. However, most of these initiatives are directed towards specific communities and tend to separate the struggles of the different groups. Facilitating collaboration between EU migrants, refugees and social movement groups committed to the struggle against poor working conditions should be at the top of the agenda. ALSO Oldenburg is an example of such an approach, as this group tries to find consultants from the different language groups present in the industry. Another challenge concerns the connection between struggles against bad housing, transportation and working conditions. Recalling the demand of the anti-racist movements for citizenship and social rights, we can say that all of these issues are deeply connected. In this sense, it can be necessary to "specialise" on one of them. However, when such specialisation leads to one issue being perceived in isolation, the approach is ultimately doomed to failure (Grüner, 2014).

Workers' power is not a substance that can be "owned" but a social relation that changes over time (Nowak, Dutta and Birke, 2018: 12). The fact that migrant workers tasked with slaughtering in the Oldenburger Münsterland have some leverage does not automatically translate into power for migrant workers in the German meatpacking industry in general, let alone into power for the working class in Germany and beyond. Using power resources is a political and strategic challenge, which includes the need to connect different strata of workers (that are constantly pitted against each other), different forms of labour unrest (within and outside the workplace) and different forms of grievances (like those related to labour, animal welfare and pollution). All of this is impossible without a perspective of radical transformation, which in the case of the meat industry includes the question of how to produce food without the brutal exploitation of humans and nature.

\section{REFERENCES}

Altenried, M., M. Bojadžijev, S. Mezzadra and M. Wallis (eds.) (2017) Logistische Grenzlandschaften. Das Regime mobiler Arbeit nach dem Sommer der Migration. Münster: Unrast.

Anderson, B. (2006) "Doing the Dirty Work?" Migrantinnen in der bezablten Hausarbeit in Europa. Hamburg/Berlin: Assoziation A.

Bojadžijev, M. (2012) Die windige Internationale. Rassismus und Kämpfe der Migration. Second edition. Münster: Westfälisches Dampfboot.

Brinkmann, U. and O. Nachtwey (2017) Postdemokratie und Industrial Citizenship. Erosionsprozesse von Demokratie und Mitbestimmung. Weinheim/Basel: Beltz.

Brücker, H., J. Croisier, Y. Kosyakova, H. Kröger, G. Pietrantuono, N. Rother and J. Schupp (2019) Zweite Welle der IAB-BAMF-SOEP-Befragung: Geflüchtete machen Fortschritte bei Sprache und Beschäftigung. LAB-Kuržbericht 03/2019. http://doku.iab.de/kurzber/2019/kb0319.pdf [accessed 9 December 2019]. 
Carstensen, L., L. Riedner and L. Heimeshoff (2018) Der Zwang zur Arbeit. Verwertungslogiken in den umkämpften Regimen der Anwerbe-, Flucht- und EU-Migration. Sozial.Geschichte Online, 22: 23-44.

Dyer, S., L. McDowell and A. Batnitzky (2010) The Impact of Migration on the Gendering of Service Work: The Case of a West London Hotel. Gender, Work and Organization, 17(6): 635-657.

Epler, J. (2014) Überzogene Mieten für Werkverträgler: Arbeiter in Bruchbuden. die tageszeitung, 15 November 2014. https://taz.de/Ueberzogene-Mieten-fuer-Werkvertraegler/!5028622// [accessed 5 August 2019].

Fiedler, M. and L. Hielscher (2017) Aus den Kreisläufen des 'Schweinesystemsı. Die Fleischindustrie im Oldenburger Münsterland als Regime von Mobilität und Ausbeutung. movements. Journal for Critical Migration and Border Regime Studies, 3(1). http://movements-journal.org/issues/04.bewegungen/12. fiedler,hielscher--kreislaeufe-schweinesystem.html [accessed 10 December 2019].

Frankfurter Allgemeine Zeitung (FAZ) (2015) Daimler-Chef Zetsche: Flüchtlinge könnten Wirtschaftswunder bringen. 15 September 2015. https://www.faz.net/aktuell/technikmotor/iaa/daimler-chef-zetsche-fluechtlinge-koennten-neues-wirtschaftswunder-ausloesen13803671.html [accessed 10 December 2019].

Gallas, A. (2018) Class Power and Union Capacities: A Research Note on the Power Resources Approach. Global Labour Journal, 9(3): 348-352.

Grüner, G. (2014) Warum Hartz IV EmpfängerInnen gezwungen sind Landarbeiter auszubeuten. Interview mit Guido Grüner. Focus Europa. https://rdl.de/beitrag/warum-hartziv-empf-ngerinnen-gezwungensind-landarbeiter-auszubeuten [accessed 7 December 2019].

Hans Böckler Stiftung (2017) Branchenmonitor Scblachten und Fleischverarbeitung. Düsseldorf. https://www.mitbestimmung.de/assets/downloads/Branchenmonitor Schlachten und Fleischverarb eitung.pdf [21.09.2018]

Heinrich Böll Stiftung (2016) Fleischatlas. https://www.bund.net/fileadmin/user upload bund/ publikationen/massentierhaltung/massentierhaltung_fleischatlas_regional_2016.pdf [accessed 21 September 2018].

Hirsch, S. and A. Peter (2015) Die neuen Tricks der Fleischmafia. Trotz Selbstverpflichtung geht die Ausbeutung weiter. Report Main: https://www.swr.de/-/id=16270638/property=download/nid= 233454/6wzipo/neue-tricks-fleischmafia.pdf [accessed 7 August 2019].

Jyllands-Posten (2017) 750 fra Horsens i konflikt med ledelse strejker, 19 May 2017. https://finans.dk/ erhverv/ECE9589920/750-slagterifolk-fra-horsens-i-konflikt-med-ledelse-strejker/?ctxref=ext [accessed 10 December 2019].

Krogmann, K. (2016) Die Lohnabrechnung? Die stimmt nie. Werkverträge in der Fleischindustrie. Nordwestzeitung, 1 Juli 2016.

LabourNet.de (2015) Polen legen Schlachtung lahm - Werkvertragsarbeiter protestieren bei Danish Crown in Essen gegen Zahlungsverzug, 28 March 2015. http://www.labournet.de/branchen/nahrung/polenlegen-schlachtung-lahmwerkvertragsarbeiter-protestieren-bei $\% \mathrm{E} 2 \% 80 \% 88$ danish-crown-in-essengegen-zahlungsverzug// [accessed 10 December 2019]

Landkreis Cloppenburg (2018) Wirtschaftsinformationen, https://www.lkclp.de/kreis-politik/zahlen-datenfakten/sozialversicherungspflichtig-beschaeftigte.php [accessed 10 December 2019].

Landkreis Vechta (2018) Wirtschaftsinformationen, Politik und Verwaltung. https://www.landkreis-vechta.de/ fileadmin/dokumente/pdf/politik_und verwaltung/LKV_Datenspiegel2018 final_Juni.pdf [accessed 10 December 2019].

Lübecker Nachrichten (LN) (2017) Birfood - Neue Zentrale - Gute Gescbäfte. 14 June 2017. http://www.lnonline.de/Nachrichten/Wirtschaft/Wirtschaft-im-Norden/Birgroup-Neue-Zentrale-gute-Geschaefte [accessed 10 December 2019].

Mayer-Ahuja, N. (2003) Wieder dienen lernen? Vom westdeutschen „Normalarbeitsverbältnis“ “ zu prekärer Beschäftigung seit 1973. Berlin: Edition Sigma. 
Mense-Petermann, U. (2018) Eastern European Service Contract Workers in the German Meat Industry A Case Study in Market Making of a Transnational Labor Market. ZiF-Mitteilungen, 2/2018: 23-31.

Mezzadra, S. and B. Neilson (2013) Border as Method, or, the Multiplication of Labor. London: Duke University Press.

Morrison, C., D. Sacchetto and O. Cretu (2013) International Migration and Labour Turnover: Workers' Agency in the Construction Sector of Russia and Italy. Studies in Transitions, States and Societies, 5(2): 7 20.

Nordwest Zeitung (2017) Arbeiter erhielten am Ende nur 4 Euro Stundenlohn. https://www.nwzonline. de/blaulicht/wildeshausen-lohne-oldenburg-prozess-in-oldenburg-arbeitererhielten a 50,1,3575343712.html [accessed 10 December 2019].

Norddeutscher Rundfunk (NDR) (2016) Ärger um Festanstellung von Leiharbeitern bei Schlachthof Goldschmaus, 14 December 2016.

Nowak, J. (2018) The Spectre of Social Democracy: A Symptomatic Reading of the Power Resources Approach. Global Labour Journal, 9(3): 353-360.

Nowak, J., M. Dutta and P. Birke (2018) Workers' Movements and Strikes in the 21th Century. A Global Perspective. London: Rowman and Littlefield.

Oldenburger Münsterland (2019), Daten zum Oldenburger Münsterland. https://www.oldenburgermuensterland.de/service/daten-region-om/? [accessed 28 January 2020].

Riedner, L. (2017) Aktivierung durch Ausschluss - Sozial- und migrationspolitische Transformationen unter den Bedingungen der EU-Freizügigkeit. movements. Journal für kritische Migrations- und Grenzregimeforschung, 3(1). http://movements-journal.org/issues/04.bewegungen/06.riedner--aktivierung-durch-ausschluss. html [accessed 10 December 2019].

Samers, M. (2014) How to Understand the Incorporation of Immigrants in European Labour Markets. In An Introduction to Immigrant Incorporation Studies: European Perspectives, edited by M. Martiniello and J. Rath. Amsterdam: Amsterdam University Press.

Scherschel, K. (2016) Citizenship by Work? Arbeitsmarkpolitik im Flüchtlingsschutz zwischen Öffnung und Selektion. PROKLA, 46(2): 245-265.

Schmalz, S., C. Ludwig and E. Webster (2018) The Power Resources Approach: Developments and Challenges. Global Labour Journal, 9(2): 113-134.

Silver, B. (2003) Forces of Labor. Workers' Movements and Globalization since 1870. London: Cambridge University Press.

Thommerel, C. (2014) Ausbeutung von migrantischen Arbeitskräften in Deutschland: zwischen Containern, Spargelfeldern und Schweinehälften. http://www.agricultures-migrations.org/ausbeutung-vonmigrantischen-arbeitskraften-in-deutschland-zwischen-containern-spargelfeldern-und-schweinehalften [accessed 8 June 2019].

Verband der Ernährungswirtschaft in Deutschland (VdEW) (2017) Selbstverpflicbtung der Fleischwirtschaft zu 100\% umgesetzt! https://www.vdew-online.de/selbstverpflichtung-der-fleischwirtschaft-zu-100umgesetzt [accessed 10 December 2019].

Wagner, I. (2015) EU Posted Work and Transnational Action in the German Meat Sector. Transfer: European Review of Labour and Research, 21(2): 201-213.

Weinkopf, C. and F. Hüttenhoff (2017) Der Mindestlohn in der Fleischwirtschaft. WSI-Mitteilungen, 70(7): 533-539. 


\section{BIOGRAPHICAL NOTES}

PETER BIRKE is senior researcher at the Sociological Research Institute Göttingen, co-editor of the journal Social History Online (sozialgeschichteonline.org) [Email: peter.birke@sofi.unigoettingen.de]

FELIX BLUHM is senior researcher at the Sociological Research Institute Göttingen [Email: felix.bluhm@sofi.uni-goettingen.de] 